Irene Dietzel

The Ecology of Coexistence and Conflict in Cyprus 


\section{Religion and Society}

Edited by

Gustavo Benavides, Kocku von Stuckrad and Winnifred Fallers Sullivan

\section{Volume 57}




\section{Irene Dietzel}

The Ecology of

Coexistence and

Conflict in Cyprus

Exploring the Religion, Nature, and Culture of a Mediterranean Island 
This book is the result of a dissertation accepted by the Faculty of Philosophy of the University of Erfurt.

ISBN 978-1-61451-344-5

e-ISBN (PDF) 978-1-61451-266-0

e-ISBN (EPUB) 978-1-5015-0013-8

ISSN 1437-5370

\section{Library of Congress Cataloging-in-Publication Data}

A CIP catalog record for this book has been applied for at the Library of Congress.

\section{Bibliographic information published by the Deutsche Nationalbibliothek}

The Deutsche Nationalbibliothek lists this publication on the Deutsche Nationalbibliografie; detailed bibliographic data are available on the Internet at http://dnb.dnb.de.

(C) 2014 Walter de Gruyter, Inc., Boston/Berlin/Munich

Printing and binding: CPI books $\mathrm{GmbH}$, Leck

(2) Printed on acid-free paper

Printed in Germany

www.degruyter.com 